\title{
Multiple Gastric Diverticula
}

\author{
Gisela Silva Helena Moreira Silva Marta D. Tavares Rosa Lima \\ Pediatric Gastroenterology Unity of Centro Materno-Infantil do Norte, Centro Hospitalar e Universitário \\ do Porto, Porto, Portugal
}

Keywords

Congenital diverticula $\cdot$ Esophageal atresia $\cdot$ Child

\section{Divertículos Gástricos Múltiplos \\ Palavras Chave \\ Divertículos congénitos · Atrésia esofágica · Criança}

A 9-year-old girl presenting with an esophageal atresia (EA) with tracheoesophageal fistula underwent surgical correction and was submitted to examination of the esophageal structure. She presented with dyspeptic complaints. Upper gastrointestinal endoscopy (UGE) showed multiple uncomplicated gastric diverticula (GD) (Fig. 1). This pathology was confirmed with a barium swallow study (Fig. 2). Reviewing the patient's record, we found a description of a pneumoperitoneum following gastric rupture before the correction of the EA. The esophagogram, performed at 50 days of life, showed good passage of the contrast material but irregular gastric filling and UGE revealed exaggerated folds and areas of small pockets in the lesser curvature of the stomach. GD are a rare endoscopic finding, with an estimated prevalence of $0.01-0.11 \%$ [1]. Most GD are single and acquired during life [1]. Usually, symptoms are unspecific [2]. Occasionally, patients with GD can have dramatic presentations related to massive bleeding or perforation [3]. The de-

\section{KARGER}

E-Mail karger@karger.com www.karger.com/pjg
(C) 2019 Sociedade Portuguesa de Gastrenterologia Published by S. Karger AG, Basel

Karger

This article is licensed under the Creative Commons AttributionNonCommercial-NoDerivatives 4.0 International License (CC BYNC-ND) (http://www.karger.com/Services/OpenAccessLicense). Usage and distribution for commercial purposes as well as any distribution of modified material requires written permission.

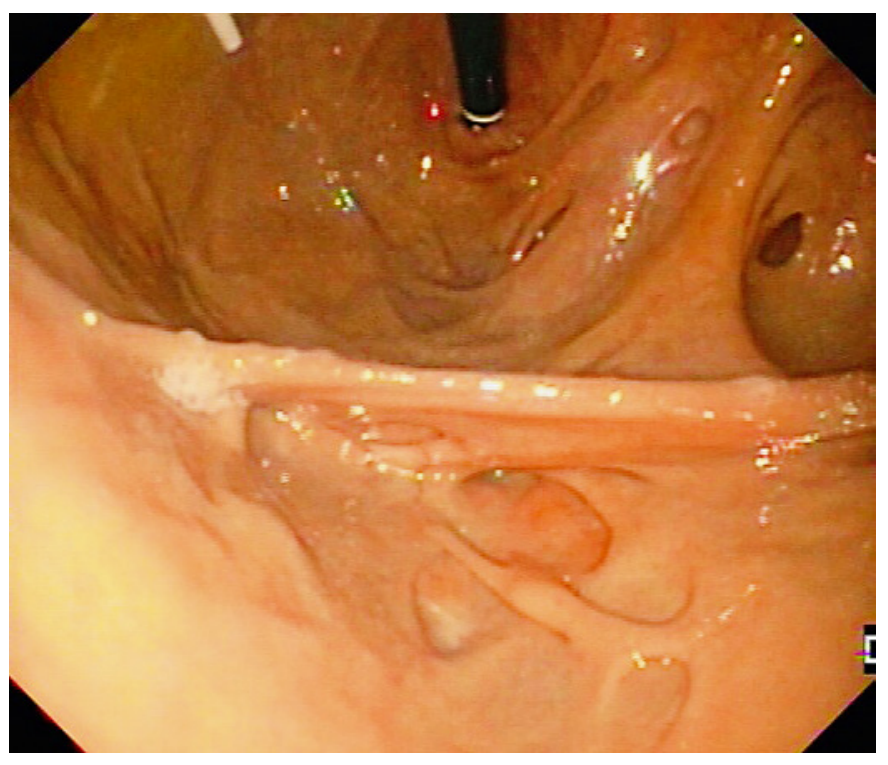

Fig. 1. Multiple uncomplicated gastric diverticula at the gastric fundus and body. Deformation of the stomach with retraction of the pylorus into the anterior wall with slight deformation is observed.

scription of a gastric rupture in the first day of life, the localization of the GD and the association with other gastrointestinal abnormalities as EA make the diagnosis in this case more likely to be multiple congenital GD $[2,3]$. This last association may be explained by embryogenesis 


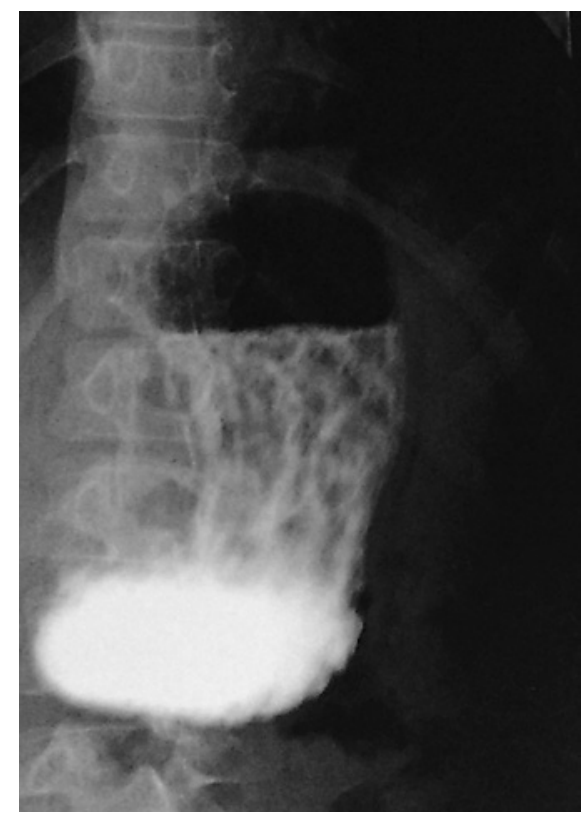

Fig. 2. Barium swallow study demonstrated tiny flash-shaped outpouchings arranged in clusters of longitudinal rows, mostly in the gastric fundus.
[3]. The surgery may have contributed to the appearance of new pseudodiverticula as a consequence of perigastric adhesions in the gastric suture itself.

\section{Statement of Ethics}

The authors have no ethical conflicts to disclose.

\section{Disclosure Statement}

The authors have no conflicts of interest to declare.

\section{References}

1 Palmer ED. Gastric diverticula. Int Abstr Surg. 1951 May;92(5):417-28.

2 Ramai D, Ofosu A, Reddy M. Gastric Diverticula: A Review and Report of Two Cases. Gastroenterol Res. 2018 Feb;11(1):68-70.

3 Cheng EH, Pavelock RR. Multiple gastrointestinal tract diverticula. Gastrointest Radiol. 1990;15(4):282-4. 